\title{
Politicizing the Pandemic: A Schemata Analysis of COVID-19 News in Two Selected Newspapers
}

\author{
Ali Haif Abbas ${ }^{1}[$ \\ Published online: 3 July 2020 \\ (c) Springer Nature B.V. 2020
}

\begin{abstract}
This article critically studies coronavirus (COVID-19) pandemic news in the press. The article attempts to study the way the news of COVID-19 is used for political and ideological purposes. In order to achieve the aim, two newspapers namely, The New York Times from the United States of America and Global Times from China are selected. Van Dijk's news schemata framework is used for the analysis of the reports selected from the two newspapers. Van Dijk's news schemata is crucial for the analysis of any news story (report) whether such a news story is taken from a news channel or a newspaper and whether broadcasted or printed. Based on data analysis, the article found out that the news of COVID-19 has been politicized and used for ideological interests. The article recommends that pandemics should not be politicized, instead we should work together to save our lives and live peacefully.
\end{abstract}

Keywords News $\cdot$ Bias $\cdot$ News schemata $\cdot$ COVID-19 pandemic

Peace is a daily, a weekly, a monthly, process, gradually changing opinions, slowly, eroding old barriers, quietly building new structures. And however, undramatic the pursuit of peace, that pursuit must go on. .

John F. Kennedy. [Address before the United Nations, September 20, 1963].

\section{Introduction}

The broadcast and print media have a very big influence on public opinion and they are major channels for communication between decision makers and the public. The power of the media stems from its influence on the crystallization of our thoughts. Thoughts serve like an engine which drives and controls our actions and behaviour. The media have the ability to work day and night for the purpose of forming

Ali Haif Abbas

ahaif@uowasit.edu.iq

1 Department of English Language and Literature, College of Education for Humanities, Wasit University, Wasit, Iraq 
perceptions, manipulations, and changing convictions, regardless of whether it is a positive or negative change, acceptable or rejected, beneficial or harmful, beloved or hated.

The media play a crucial role in revolutions, especially Arab Spring uprisings, the war on terror, and international security. The media depend on conveying or transmitting news and creating a dialogue between governments and people and between different parties in a certain country or society. The media have also played a crucial role in political campaigns, peace, and conflict studies. The media, therefore, are the medium by which people can raise their concerns, problems, and needs to their governments. The media have become a tool of pressure. They can easily agitate the public opinion by raising specific as well as sensitive issues. They can also agitate people by resorting to manipulation, persuasion, distortion, and deception.

Nelson [17] states that:

Bias is the predisposition for or against a particular point of view. Whenever the positions or interests of a portion of the audience are overlooked, distorted, or censored the problem of bias is found. Bias may result from unintentional or deliberate decisions on the part of media gatekeepers, but nevertheless subjects audiences to a skewed reality potentially detrimental to their best interests (2)

Hofstetter and Buss [9] illustrate that Polemics about the word 'bias' in ordinary language is basically slanted. In other words, bias presents something such as a news story in a way that favors a particular group or opinion (bias interprets or presents someone or something in an ideological way for special interests). Bias also reports certain issues, problems, actors, politicians, and any other political event not as they really are. Bias is not free from lying, distortion of and diffusing certain facts, disagreement over basic values, beliefs or mores.

Mullainathan and Shleifer [15] stress the fact that information can be manipulated by different ways: ignoring or omitting information that is opposite to or inconsistent with the message of the news story, finding information sources that can reinforce or strengthen the story, ignoring, neglecting, and undermining information sources that are incompatible with the message, or using misleading and deceitful language and images that support the story.

Undoubtedly, media bias, news bias, and manipulation of information cannot be achieved without the language. Language serves as a powerful tool by which media owners depend on in conveying their ideologies and manipulations [22]. Kolsto [12] argues that the media are politically controlled. This political control has great impact over its response to any kind of crisis or event.

\section{Politicizing Pandemics}

Politicizing pandemics is not a new bad and negative issue which we as humans need to get rid of. History proved that pandemics were politicized and used for ideological and political interests. Dangerous diseases such as the 1918 H1N1 flu, AIDS, Ebola were politicized [1, 6, 20, 21]. 
In fact, history does not repeat itself, but it teaches us lessons and inspires us to response and act differently to current crises to get positive and good results of our negative previous ones. Sadly, we have not learned a lesson from our previous and disastrous crises; instead we stubbornly politicize and invest the current deadly COVID-19 pandemic for political and ideological purposes. Scott [21] emphasizes that disease and responses to disease are always politicized and have always political consequences. Ebola virus is politicized just like other previous viruses. COVID-19 is a virus like other previous viruses such as plague, $1918 \mathrm{flu}$, Asian flu, Cholera, AIDS, SARS, Ebola, Zika, SARS, and MERS. It is a virus and this is the law of nature. Instead of cooperating together to defeat such a deadly disease, governments, especially those in power are busy exchanging accusations. Zhao Lijian, the spokesperson of China's Ministry of Foreign Affairs accused the United States of America of spreading the pandemic in Wuhan, the epicenter of COVID-19 outbreak [10, 16]. President Trump responded by labeling the virus as "Chinese virus". Then, his Secretary of State Mike Pompeo called the virus as "Wuhan virus" [14]. Exchanging accusations between China and US continues. The US even asked to open an investigation which links the virus to Wuhan labs.

Page [18] emphasizes that politicizing the pandemic is hazardous to national health. Stigmatizing a nation or country for its supposed responsibility in a calamity does not produce a vaccine or medicine for the virus, but rather complicates it. When racism, stereotypes, hate speech, and propaganda are combined with intense fear and terror from a disease, more problems will definitely emerge. The media and means of social communication can make the situation even harder than expected. Distorted and false information, manipulation, ideology, conspiracy theory, undocumented claims, and inaccurate conclusions can spread quicker than the virus itself. Politicizing pandemics and broadcasting fear and hate speech will lead to the discrimination and stigmatization of "others" in a wrong, thoughtless, and bad way [6]. Politicizing diseases shaped and can shape public attitudes about immigration. The Chinese Exclusion Act was the first immigration law passed in 1882. Due to disease threat and after decades of stereotyping Chinese immigrants and believing that Chinese carry diseases such as cholera and smallpox, the law prevented Chinese from immigrating to the United States. The Scott Act of 1888 was introduced to heavily restrict and prevent Chinese to immigrate to the US. Such laws and views hurt an entire community and at the same time they did not stop the spread of diseases. The pandemic flu which was first identified in China during the end of 1950s was known as "Asian Flu". The other flu pandemic that was appeared in Hong Kong during the end of 1960s was called "Hong Kong Flu". The 2009-2010 H1N1 flu which was first identified in the US was called "swine flu". Media coverage of this flu emphasized that this flu might have come from Mexico which again caused fears from immigrants [13].

Politicizing pandemics encourages ethnic and racial discrimination among different people, societies, and countries. It creates political, social, and even health problems. It also pushes people to indulge in hate speech and aggression. Therefore, we should avoid disinformation, distortion, racial rhetoric, slur expressions, ideology, manipulation, and propaganda. In other words, we should work together 
to control the disease and overcome it. In the end, viruses do not know borders and do not distinguish between colors, religions, and creeds.

\section{Van Dijk's [23-26] News Schemata}

Bukhari and Xiaoyang [3] elucidate that Van Dijk put up the analysis of 'structures at various levels of description' ranging from phonological, morphological, grammatical, and semantic levels to higher levels such as coherence, themes and topics related to different news stories and other whole schematic and rhetorical dimensions of texts.

Yarlott et al. [28] state that:

Discourse structure is a key aspect of all forms of text, providing valuable information about the contents of a given span of text. This is most obvious in academic, legal, and technical texts, which are often clearly delineated into sections containing, for example, introductory, background, or explanatory material, among others - these type of texts are designed to make it easy to find specific information within them quickly. News articles have a similarly helpful, though implicit, design: they often provide a brief, up-front summary of the important events, relevant background information, comments from both experts and the reporters, and detailed descriptions of the main events. Events are often not presented in chronological order, but rather structured by importance (25).

Drid [7] illustrates Van Dijk's framework for the analysis of the discourse of news depends on two systematic ranks of structures: global structures and local structures. The global structures consist of two discourse structures, namely macrostructures and superstructures. The local structures include the microstructures.

Zhang et al. [29] state that:

Van Dijk's study of news discourse has his peculiar feature. He believes that discourse is a kind of social control power, which represents the willpower of authority, and reflects special power structure. The people who control and spread discourse are news journalists, writers, artists and scholars. These people are called "symbolic elites". The powerful people are entitled to control all kinds of discourse, while common people are only able to control daily conversation. The aim of Van Dijk's study is to observe in what ways the powerful people implement, express, describe or conceal their ambition through context and discourse. In particular, he pays much attention to the role of ideology; he had made amounts of media discourse surveys, such as news report, TV program, and advertisement. His purpose is to illustrate how western authorities control the form and content of discourse, and further control the belief and ideology of society (200-201).

Van Dijk's [23-26] study news as discourse. All of these studies give authors useful frameworks (news schemata) for analyzing any news story or report from 
any channel or newspaper. The three discourse structures namely, macrostructures, superstructures, and microstructures are crucial for the analysis of the selected news reports.

\section{Macrostructures}

The macrostructure of discourse is thematic. In other words, macrostructure is the main subject or topic that is being discussed or described and on which the whole story is based on. Thematic analysis is concerned with the main theme or topic of a certain text. Topics and themes illustrate and uncover different social as well as psychological proportions of any text or news story $[19,26]$. In news reports or stories, the macrostructure is often expressed in the headline and the lead paragraph.

\section{Superstructures}

The superstructure is schematic. It shows the main parts of a news story and the way it is arranged or organized. The superstructures of a news story consist of three main parts: they are introduction, substance, and conclusion. The news story consists of an introduction (represented by the first paragraph of the story), a substance (content) (the essence or the main story), and a conclusion (closing) (the last part, the result or the outcome of a news story) $[2,26]$.

\section{Microstructures}

The local structure of discourse is concerned with semantic, syntactic, stylistic, and rhetorical aspects of a given text [2]. It focuses on the selected lexical items (words) and sentences that are used to form a news story. According to Van Dijk [26], a news story is not free from the following different aspects of meaning: presuppositions, implications, inferences, concealments, euphemisms, disclaiming denials, blaming the victim, negativization, and in general the combined strategy of positive self-presentation and negative other-presentation. Many of these semantic features involve various forms of implicitness or indirectness (177). All of such aspects of meaning within their hidden ideologies cannot be discovered without the help of the microstructure of discourse (Fig. 1).

Van Dijk's [26] lists important questions that should be answered during the analysis of any text, especially if the analysed text is a news story:

1. How is the topical information organized in the text?

2. What tends to be given prominence, what information is presented first, and what information last?

3. Which news schema categories are emphasized, and why? 


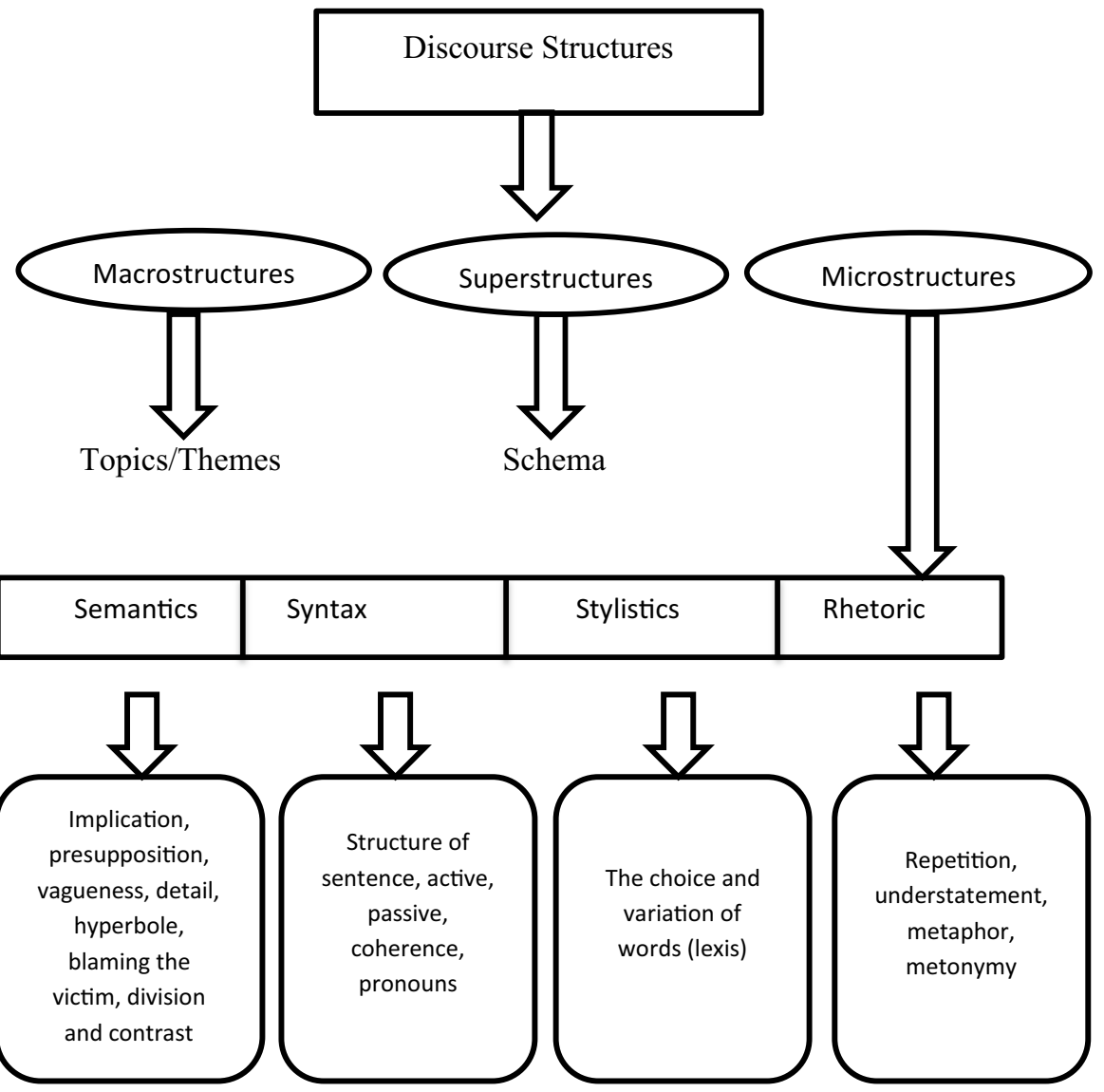

Fig. 1 The three main structures of discourse

\section{Corona Virus (COVID-19)}

Coronaviruses are a family of viruses that are found in animals and humans; certain types cause illnesses in people. Some coronaviruses cause the common cold; others cause diseases which are much more severe such as Middle East Respiratory Syndrome (MERS) and Severe Acute Respiratory Syndrome (SARS), both of which often lead to pneumonia. On 30th January 2020, WHO declared the outbreak of COVID-19 a "Public Health Emergency of International Concern" (PHEIC) [4].

On 31 December 2019, a cluster of pneumonia cases of unknown aetiology was reported in Wuhan, Hubei Province, China. On 9 January 2020, China's CDC reported a novel coronavirus as the main cause of this outbreak, which is phylogenetically in the SARS-CoV clade. The disease associated to it is now known as novel coronavirus disease 2019 (COVID-19)) [8].

Most of the patients that are suffering from COVID-19 are adults and old. The main symptoms of the pandemic are fever, dry cough, and difficulties (shortness) in 
breathing. $80 \%$ of COVID-19 patients suffered from mild illness, $14 \%$ experienced severe disease, and $6 \%$ suffered from critical illness. Illness severity is associated with age (over $60 \mathrm{~s}$ ) and other comorbid conditions [8, 27].

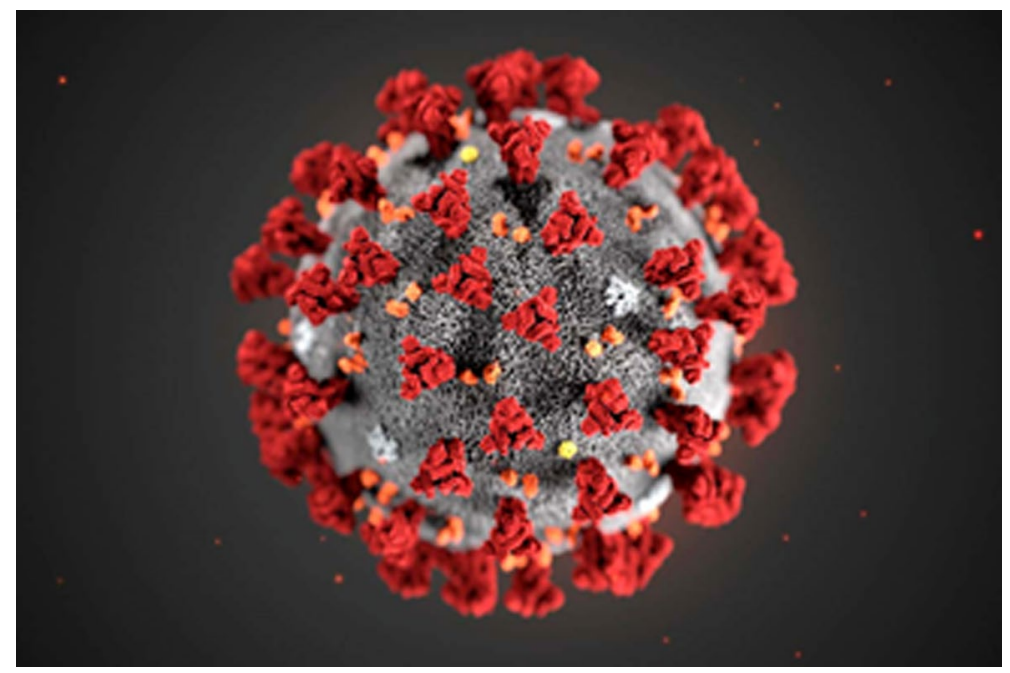

\section{Illustration of the ultrastructure of the Covid-19 virus-CDC/SCIENCE PHOTO LIBRARY [11]}

According to Johns Hopkins University and Medicine [5], the pandemic has sickened more than six million and at least 369,000 victims have died. Unfortunately, numbers of infection and death are increasing.

\section{Method}

In order to achieve the aim of the study, it is important to give a clear description of the data that are used for the analysis. The data are (4) news reports about Coronavirus taken from two newspapers namely, The New York Times from the United Sates and Global Times from China. Two news reports are analysed for each newspaper. The study aims to show and prove how the virus has been used politically in the media. The news reports are taken from the main websites of the selected news channels and newspapers. The approach that is followed for the analysis is Van Dijk's news schemata framework which is presented in detail in section two above. The news reports are analysed according to the three main discourse structures, namely the macrostructures, superstructures, and microstructures. 


\section{Data Analysis}

This section is concerned with the analysis of the selected news reports which are taken from the two selected newspapers, namely The New York Times and Global Times. The news reports are analysed according to Van Dijk's news schemata analysis of the three discourse structures, namely the macrostructure, the superstructure, and the microstructure. Tables 1 and 2 give a short summary of the selected news reports from both newspapers. The tables compare in brief the reports of The New York Times with those of Global Times in terms of the choice of headlines, length, and key-features:

\subsection{The New York Times News Schemata Analysis}

The two selected news stories from the New York Times are analysed according to the three schematic structures: macrostructure, superstructure, and microstructure.

\subsubsection{Report 1}

In terms of macrostructure, the first report of the New York Times has the following headline (China Clamps Down on Coronavirus Coverage as Cases Surge). Undoubtedly, headlines are crucial in showing the main themes or topics of a news story. Through the help of headlines, one can understand what the stories are talking about. Starting with the first headline, the phrasal verb 'clamps down' means to stop or limit the activity of coronavirus outbreak. The word 'surge' means 'to move very quickly and suddenly in a particular direction'. One

Table 1 The New York times reports summary

\begin{tabular}{ll}
\hline $\begin{array}{l}\text { First news story: published } 6 \text { February } \\
2020\end{array}$ & \\
Headline & China clamps down on coronavirus coverage as cases surge \\
Length & 1526 words \\
Key features & $\begin{array}{l}\text { The report focuses on the shortcomings of the Commu- } \\
\text { nist government and its inability to contain the outbreak } \\
\text { and provide supplies for the people. The research also } \\
\text { focuses on the public frustrations due to the spread of the } \\
\text { pandemic }\end{array}$ \\
$\begin{array}{l}\text { Second news story: published 28 February } \\
2020\end{array}$ & $\begin{array}{l}\text { Coronavirus weakens China's powerful Propaganda machine } \\
\text { Headline } \\
\text { Length }\end{array}$ \\
$\begin{array}{l}\text { Key features } \\
\text { The report focuses on the idea that China's power and great- } \\
\text { ness are just propaganda and that it couldn't contain the } \\
\text { coronavirus threat. It also focuses on the official media and } \\
\text { their propaganda about the government's fake victories } \\
\text { over the virus }\end{array}$ \\
\hline
\end{tabular}


Table 2 The global times reports summary

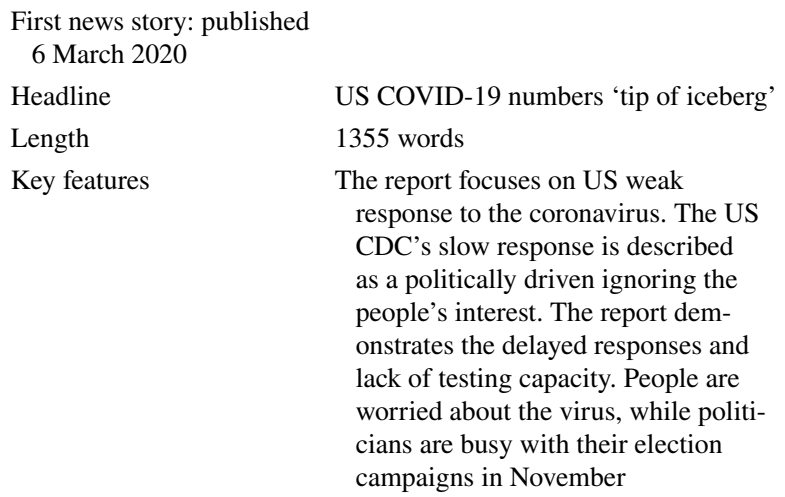

Second news story: published 1 March 2020

Headline

Length

Key features

\section{US scrambles to tackle virus 1225}

The report focuses on the political factors, testing delay, and insufficient awareness that are hindering the control of the virus in the US. The report also focuses on the more cases of COVID-19 that will be identified in the coming days. Many Americans avoid seeing doctors due to the high cost of the American healthcare system

proposition that might emerge from this headline is that China is unable to stop the spread of the outbreak. Although China clamps down on coronavirus but it is moving and spreading faster. Another proposition which can be extracted is that China's efforts to limit or stop the outbreak might not be real or effective.

In terms of superstructure, the introduction of the first report presents the failure of the 'communist government' to control the pandemic. According to New York Times, the government cannot control the pandemic; therefore, it puts its efforts on the media to strengthen its propaganda of controlling the disease. But the government control of the virus is just a narrative and a lie (As the number of coronavirus infections in China continues to surge, the Communist government has clamped down on the news media and the internet, signaling an effort to control the narrative about a crisis that has become a once-in-a-generation challenge for leaders in Beijing). The substance develops the first paragraph and gives more stories about the failure of the communist government in controlling the spread of the outbreak. Stories with more contextual details talk about the hundreds victims of the virus, thousands of confirmed infections, public frustration running across the country due to the government's weaknesses in controlling the pandemic, and official media propaganda talks about virus relief efforts. The 
government is presented negatively doing negative and irresponsible acts such as removing a range of articles talking about the shortcomings of the government's slow and weak response to the outbreak and reprimanding people who give factual cases of the illness. The report emphasizes the lack of medical supplies and face mask production which are described as running short and in overdrive, and shortage of testing kits. The report also describes the government as weak relying on media to broadcast propaganda and positive stories on its efforts to contain the virus. The conclusion ends with the scientists in China and their efforts to find a drug to stop the outbreak.

The microstructure deals with all the semantic, syntactic, lexical, and rhetorical aspects of discourse, and in this case a news report. In terms of semantics, more contextual details are devoted to the communist government and its inability to control the virus. The report is full of propaganda (fake) positive stories regarding the government strength and potential in controlling the virus. The number of the dead victims and confirmed cases, the government propaganda, its restrictions on media, social media, and freedom of speech are reported in details. All of the stories that are related to the restrictions of internet platforms implicate and presuppose a totalitarian system of government in which a single authoritarian party controls state-owned means of production. Blaming the victim and division and contrast strategies are used clearly through the report. The negative OTHERS representation is reported clearly through blaming the Chinese government of shortcomings and restrictions.

In terms of syntax, the structure of sentences illustrates the stories of the report clearly and coherently without any vagueness, especially when the stories are related to the government's shortcomings in controlling the virus, the number of the victims who lost their lives due to the pandemic, and the confirmed new cases. The New York Times uses active voice and simple tenses in order to make events clear and deductive. The news stories especially those that are related to the government's weaknesses and shortcomings in controlling the virus are written with complex sentences full of cohesive ties and conjunctions to describe the difficult and complex situation in China (As supplies run short, face mask production runs in overdrive, the rapidly rising number of infections and deaths from the new virus has put renewed pressure on the senior leadership in China. Hospitals near the center of the epidemic have been overwhelmed, and people with flulike symptoms have been turned away. Many cases have not been diagnosed because of a shortage of testing kits).

In terms of lexis, all the report is negative and its language is critical, criticizing the 'communist government' and its inability to fight the virus. Negative words that carry strong connotations are used in the report. Words and phrases such as frustrations, rigorously, communism, crisis, fear, shortcomings, propaganda, short, shortage, overdrive, turned away, forbidden, blocked, and gloom are clearly used in the report. All of these words are used to negatively refer to the Chinese government. The prominent image of the Chinese government is that of a communist-authoritarian one that uses its own ideologies and propaganda. Another image is that of deficient government incapable of controlling a virus and providing medical supplies and services to its people. The prominent image of the Chinese people is associated 
with frustration (a deep chronic sense or state of insecurity and dissatisfaction arising from unsolved problems or unfulfilled needs).

In terms of rhetoric, the phrase "communist government" has negative connotations. It is associated with harshness and totalitarianism (all the citizens should be totally subject to an absolute state authority). In the report, the communist government in China and its propaganda is highly emphasized. Propaganda is a symbol of manipulation, control, distortion, half-truths or lies. It is used to refer to the 'communist government' in China. Repetition is used through the reports. All the negative stories that are related to the shortcomings of the Chinese government in controlling the pandemic and in providing medical services and people's fears and frustrations due to the government's weaknesses are always repeated in the report.

\subsubsection{Report 2}

In the second headline which is entitled (Coronavirus Weakens China's Powerful Propaganda Machine), the phrase "China's powerful propaganda machine" is used to invite the reader to believe in the idea (proposition) that China is not really powerful and its power is just propaganda in the sense that it is unable to contain as well as overcome an unseen virus. A very tiny and unseen virus manages to weaken its power. Another proposition can be emerged from this headline is that China's power is just an illusion. This illusion is made real by the official Chinese media.

The superstructure of a news report looks on how the parts of the report namely the introduction, the substance, and the conclusion are arranged and which events are emphasized and given prominence. The New York Times gives more emphasis and prominence to the government's propaganda and totalitarianism. The introduction comes under the title (Beijing is pushing tales of perseverance, but many young people are openly questioning the Communist Party's message). According to The New York Times, the perseverance of Beijing is just a tale or fiction, not an actual fact. People in China do not believe or are frustrated with these fake tales of stability, steadfastness, and perseverance. The substance again and again supports the introduction with different negative stories of failure, rigidity, and shortcomings. The government's failure in controlling the virus is presented clearly in the reports (Beijing is tapping its old propaganda playbook as it battles the relentless coronavirus outbreak, the problem for China's leaders: This time, it isn't working so well). In The New York Times, Chinese government is always associated with rigidity, hardness, and severity. It is a rigid system towards its people and medical staff. It is also powerless unable to provide medical equipment and supplies (The government was slow to disclose the threat of the coronavirus and worked to suppress the voices of those who tried to warn the country, Exhausted medical workers with faces lined from hours of wearing goggles and surgical masks. Women with shaved heads, a gesture of devotion. Retirees who donate their life savings anonymously in government offices). The conclusion ends with Ms. Xia story whose Weibo account has been suspended for 30 days for her epidemic-related posts and that she was determined to keep on speaking whatever censorship is. The New York Times finishes the report with a quotation for Ms. Xia (Speak up as much as your courage allows," she said. "In the end, it's better than saying nothing). 
The microstructure uses semantic, syntactic, lexical, and rhetorical tools to uncover hidden ideologies in news stories. In terms of semantics, The New York Times again gives more contextual details to the government's propaganda that is used through its official media. According to The New York Times, the government has gained nothing against the virus. Their achievements against the pandemic are just lies. The report is full of stories related to the government's 'powerful' propaganda as well as opposite stories related to the shortcomings and harsh-totalitarian treatment of medical staff. Consider this quotation (Beijing is tapping its old propaganda playbook as it battles the relentless coronavirus outbreak, the biggest challenge to its legitimacy in decades. State media is filling smartphones and airwaves with images and tales of unity and sacrifice aimed at uniting the people behind Beijing's rule. It even briefly offered up cartoon mascots named Jiangshan Jiao and Hongqi Man, characters meant to stir patriotic feelings among the young during the crisis). Blaming the victim and theme of negative other representation are clearly used in the report. Even the unity that state media call for is not meant to fight the pandemic but it is meant to unite the people behind 'Beijing rule'. Consider these quotations (Exhausted medical workers with faces lined from hours of wearing goggles and surgical masks. Women with shaved heads, a gesture of devotion. Retirees who donate their life savings anonymously in government offices, People are also angry about state media accounts of female medical workers who shave their heads). Although the idea of women shaving their heads has been repeated but The New York Times does not mention the reason. The purpose behind women shaving their heads remains vague. Division and contrast strategy also repeated in the report. A contrast or comparison between the Government's propaganda with its positive tales of unity and strength and the negative role of the government which is represented by its shortcomings and harsh treatment and censorship of people are mentioned repeatedly in the report.

In terms of syntax, the structures of sentences are simple and clear. Anyone can understand the stories of the report, especially those related to Chinese propaganda, negative and bad treatment of medical staff and women, shortcomings of the government in controlling the outbreak and providing enough medical supplies. All the basic elements of a good narrative are found in the report. The report has orientation, characterization, and complication ("If we can't become a whistle-blower like Li Wenliang, then let's be a person who can hear the whistle blowing," Yan Lianke, a novelist, said in a lecture at Hong Kong University of Science and Technology in February). The hot news sense of the perfect used in The New York Times is remarkable. The New York Times uses perfect tense when it talks about sorrowful stories (China's propaganda spinners have some tough competition. Chinese people have seen images of a young woman crying "Mom! Mom!" as her mother's body was driven away. They've seen a woman banging a homemade gong from her balcony while begging for a hospital bed. They've seen an exhausted nurse breaking down and howling. And they have all seen the face of Li Wenliang, the doctor who tried to warn China about the very virus that killed him). Agency is used clearly in the report. The New York Times uses agency to highlight responsibility (The government was slow to disclose the threat of the coronavirus and worked to suppress 
the voices of those who tried to warn the country, Beijing has intensified internet censorship in the past few weeks).

In terms of lexis, the negative discourse or the image of negative other representation is clearly used in the report. Negative stories of the government's shortcomings in controlling the virus and in providing medical supplies and bad treatment of medical staff, monitoring people, suspending and deleting social accounts and posts that talk and provide information about the spread of the outbreak are clearly used in all the report. The whole report is negative. The New York Times uses many negative words and phrases such as exhausted, devotion, problem, criticizing, harshly condemned, lack, scorn, pressured, funeral, propaganda, biggest challenges, suppress, young woman crying, breaking down, howling, authoritarian government, silencing, façade of omnipotent government, blatantly unbelievable, angry, confused, people did not cheer, intensified, deleted, suspended, and tighter limits. The prominent image of the Chinese government is that of a totalitarian government with its people and medical staff. Another image of the Chinese government is that it is always associated with shortage, failure, and deficiency. The image of the people and medical workers are associated with confusion, exhaustion, fatigue, and anger. The image of women (medical workers) with shaved hair is associated with devotion and defeminization.

In terms of rhetoric, the report is not free from metaphor (that powerful tool that can be invested for ideological purposes). China's power is compared to a machine of propaganda. This machine has been weakened by a very tiny virus. The image of women with shaved hair is a symbol of devotion, obedience, and defeminization. The New York Times even questions whether shaving women's hair comes from complete satisfaction or under extreme pressure? War metaphor is used in the sentence (Beijing is tapping its old propaganda playbook as it battles the relentless coronavirus outbreak). Beijing is compared to a force battling a relentless coronavirus outbreak. This force is not fully equipped and arranged to fight such a heartless, ruthless, and dangerous enemy. Beijing is only equipped with false and exaggerated statements and ideas. This cannot beat a dangerous enemy like corona and win the battle. In terms of repetition, government's propaganda has been repeated to emphasize that Beijing's power is just propaganda unable to fight a dangerous enemy like corona. Government's shortcomings in controlling the virus as well as providing medical supplies are also repeated many times in the report. Women with shaved hair are also repeated and it serves as a sign of devotion and obedience to the government. The story of Dr. Li Wenliang and other people, the first doctor who warned the people from the new novel coronavirus is repeated many times in the report as a sign to refer to the totalitarian system in China (The crisis has exposed many people, especially the young, to troubling aspects of life under an authoritarian government. In the silencing of people like Dr. Li, they see the danger in clamping down on free expression). The repetition of cartoon mascots named Jiangshan Jiao (lovely land) the name of the girl comes from a line in a poem entitled 'snow' by Mao Zedong (how lovely is this land) with her handsome male and Hongqi Man (free spirited red flag) his name also comes from a line in the poem. According to The New York Times, the idea behind this carton is to broadcast tales of unity and sacrifice behind Beijing's rule. 


\subsection{The Global Times News Schemata Analysis}

\subsubsection{Report 1}

In terms of macrostructure, the first headline entitled (US COVID-19 numbers 'tip of iceberg') is used to refer to the number of cases of coronavirus in the US. The numbers are described as 'tip of iceberg'. According to Global Times, the few numbers of COVID-19 cases in the US are just tip of iceberg and that the huge mass of the iceberg will appear with the next coming days or weeks. The headline implies the following proposition: there is a much bigger iceberg beyond this small tip.

The superstructure of any discourse looks on how the events are arranged in terms of introduction, substance, and conclusion on one hand and what events are given more emphasis and prominent on the other. The introduction illustrates that the US government and officials have harshly criticized China's response to the coronavirus epidemic, but then they have been caught under heavy fire for their response to the coronavirus outbreak in the country. People are described as frustrated due to the rising numbers of new cases and the government's insufficient efforts to control the virus. According to Global Times, some Americans (have even dubbed the US government's response a "national scandal" that puts the fundamental interests of Americans in jeopardy). The substance obviously supports the introduction through giving many stories related to the government's slow response to the outbreak as well as the shortcomings in the healthcare system. Trump's administration is described as retarded and incompetence which has put many states in a state of emergency. The US CDC's slow response is described as (is politically driven, totally ignoring the public interest). Testing in the US states is described as 'flawed'. The report also emphasized the fundamental contrast between China's government responses to the outbreak with that of Trump's administration. China quickly responded adjusted measures to control the spread, while the US response (has now become shift-blame-tactics between the White House and US CDC). Some people in the US are described as (worried about this new disease and its high contagiousness, particularly as politicians are focused on campaigning for elections in November). The conclusion ends with the importance of the Chinese and US cooperation and the need for this cooperation as the two global powers can work together to overcome the outbreak. The conclusion also emphasizes that the US's CDC should share information on developments in COVID-19 and that it should provide regular reports to the World Health Organization.

In terms of microstructure, the first microstructure strategy is semantics. In terms of semantics, more contextual details are given to Trump's administration, US's CDC weaknesses, frustrated people and their worries due to the virus spread, and insufficient American healthcare system. The phrase 'tip of iceberg' which is used to refer to the number of cases of COVID-19 in the US implies that the numbers will increase with the next days. The tip of iceberg presupposes that there will be an iceberg formed by people with COVID-19. The sentence 'citizens are demanding full transparency from officials' implies that the US officials are not giving the people accurate information regarding the number of people with COVID-19 and the spread of the outbreak. The sentence (the US's CDC has stopped reporting the 
number of people tested for the novel coronavirus) implies a sense of suspicion, a feeling that something bad is likely or true. The word 'some' is mentioned (10) times in the report. Some is associated with vagueness. Sentences such as (Some have even dubbed the US government's response a "national scandal" that puts the fundamental interests of Americans in jeopardy, some projections came up with real numbers far higher than those reported) are associated with an indefinite amount and unspecified number. Blaming the victim and contrast and division strategies are also used in the report. The report is full of blaming, blaming of the US insufficient responses and 'bungled' efforts to control the virus, the 'retarded response and incompetence' of the Trump administration. The newspaper blames the US CDC's slow response, describing it as politically driven and ignoring public interest. Division and contrast strategy is also used in the report. Global Times compares between the sufficient response of the Chinese government and the insufficient response of Trump's administration to the outbreak.

In terms of syntax, most of the stories of the report are written in the past simple tense (the best tense for narrating stories). The sentences are written clearly in active form. Passive voice is not used in the report. Global Times also used the present perfect tense-the preferable tense for hot news, events or stories (Trump administration has placed several states in a state of emergency; $(C D C)$ has stopped reporting the number of people tested for the novel coronavirus pneumonia). Most of the stories are supported by clear agency or characterization, complication, and orientation (giving places and times). Consider this story (Robert Murphy, an infectious diseases professor in the US and executive director of the Institute for Global Health at the Northwestern University Feinberg School of Medicine, told the Global Times in an email on Wednesday that he agrees with those who say the CDC has been making the same mistakes as Wuhan at the beginning of the outbreak, which included narrow testing criteria, slow testing speed and lack of testing capacity resulting in the delayed response).

In terms of lexis, the prominent image of the US is associated with deficiency and insufficiency in providing testing kits and firm-decisive efforts to stop the pandemic spread. The prominent image of people is associated with frustration, wonder, and worry about the disease. Citizens are also presented as powerful actors criticizing the country's insufficient efforts to contain the virus. Politicians are busy with their election campaigns and do not want the disease to influence their polls. The discourse of SELF and OTHER is clearly used in the report. The SELF discourse is always good and positive, while the OTHER discourse is always bad and negative. China is represented as a positive country which is able to control the pandemic in contrast to the US (the central government quickly stepped in and adjusted responding measures. In contrast, it has now become shift-blame-tactics between the White House and $U S C D C$ ). China is also described as a positive country ready to cooperate, work together, share responsibility, and give advice. Consider this story (Wang Guangfa, a leading Chinese respiratory expert at Peking University First Hospital in Beijing, urged the US CDC to share information on developments in the COVID19 outbreak in the US and take concrete steps to contain the spread of the virus with health departments of other major countries plagued by the virus, and also provide regular reports to the World Health Organization). 
In terms of rhetoric, the phrase 'tip of iceberg' is a metaphor meaning that there is a lot more of COVID-19 cases than meets the eye. In the sentence 'the US government and officials are caught under heavy fire for their response to the coronavirus outbreak in the country', the heavy fire is a metaphor for fear, rage, and anger, anger of the citizens due to the US's insufficient efforts. Repetition, as an ideological rhetorical strategy, is used to negatively represent the US. The US government and Trump's administration are repeated for their shortages in controlling the virus. The US's CDC is repeated (18) times for its slowness and weaknesses in dealing with the pandemic. People are repeated criticizing the government's slow response to the outbreak. The image of fear and worry in people is also repeated in the report. China is repeated positively giving advice and offering cooperation.

\subsubsection{Report 2}

The second headline entitled (US scrambles to tackle virus) means that the US is unable to deal with a very tiny virus. The headline is written in the present simple tense to make it more factual. The verb 'scramble' means 'to struggle with difficulty'. The US is struggling with a virus and this virus is not easy to deal with.

In terms of superstructure, the introduction illustrates the factors that are hindering the White House's readiness for the virus. The main two impediments are political factors and testing delay. The introduction also puts more emphasis on Western and American media which have harshly criticized China's government response to the outbreak, but it happened that the virus have crept to Western countries due to their insufficient awareness and few control measures in place to check its spread. The substance supports the introduction and gives many different stories on the causes that will jeopardize the virus-control work and undermine the fundamental interests of the American public. Such causes are finger-pointing, partisan politics and presidential election. In the report, Trump is described as having little understanding about the pandemic. Ill-preparation, shortages of medical supplies, flaws in the US healthcare system, lack of consistent commitment and coordination, unprofessional response, lack of information transparency related to the disease, and expensive American healthcare system are other causes which help increase the spread and the risk of the virus. The report ends with a conditional conclusion that (if the US fails to contain the viral spread, it would be a heavy blow not only to the US itself but also to the world's economic recovery).

The first microstructure strategy is semantics. More stories supported by contextual details are given to the negative causes that allow the virus to spread in the US. Stories related to ill-preparation, weaknesses in the political and administrative system, and deficiencies in the US's CDC and healthcare system are the most prominent and emphasized stories in the whole report. Such negative stories are preferable and prominent. The indefinite quantifier "some" is mentioned (6) times in the report. Although "some" is used to refer to indefinite number and amount, it used in Global Times reports. Phrases such as some observers, some raised questions, some critics, and some analysts are used in the report to give supports to the negative stories related to the shortcomings of the US government in dealing with the pandemic. The quotation (US President Donald Trump mistakenly described the patient, who 
was a man in his 50 s, as a "wonderful women") illustrates that Global Times always emphasizes confusion, bewilderment, and chaos in the US. Blaming the victim is clearly used in the report. Global times puts the blame on the US government under Trump's administration and US's CDC for their shortages and ill-preparation regarding the spread of the outbreak.

In terms of syntax, the report is clear and cohesive. The sentence structure is presented clearly without vagueness. Active voice and agency are presented obviously in the report for no other purpose than to highlight the responsibility of the US government, Trump, and US's CDC. The newspaper does not use passive. It seems that Global Times does not want to mitigate or hide the responsibility behind the spread of the virus in the US, and the shortcomings and lack of medical supplies. All such negative stories are highlighted and given more prominence in the report. The report contains all the basic elements of a good narrative. The report includes agency, complications or different cohesive ties and conjunctions. Consider this quotation (However, US President Donald Trump mistakenly described the patient, who was a man in his $50 \mathrm{~s}$, as a "wonderful woman" during a press conference while the US Centers for Disease Control and Prevention (CDC) later took the blame by claiming it mistakenly identified the patient as female in a briefing to Trump and US vice president Mike Pence, who is now overseeing the US federal government's response to the outbreak).

In terms of lexis, the language of the report is negative full of negative stories and words. Powerful words and phrases with complex modifications and adjectives are widely used such as failure, insufficient awareness, few control measure, finger-pointing, partisan politics, death, ill-prepared, CDC's faulty mass screenings, highly possible shortages, criticism, flaws, lack, wrong, loopholes, lack of consistent commitment, hasty and unprofessional response to the outbreak, shortcomings, failed, raising fears, overwhelmed, problem, slow response, anxious. The prominent image of the US and Trump is associated with finger-pointing, confusion, lack of correct decisions, loopholes, shortcomings, ill-preparation, unprofessional and slow response to the outbreak. The prominent image of people is associated with anxiety. They are anxious (as the facts are still unknown, urging the US government to cope with the matter in a more responsible way).

In terms of rhetoric, repetition is the most rhetorical device that is used in this report. Most of the negative stories are repeated in the report. The US's government shortcomings in controlling the virus are repeated. The US's CDC slow and unprofessional response to the disease is repeated. The expensive American healthcare system is repeated. People's concerns about and criticism to the slow and weakness response of the government are also repeated.

\section{Conclusions}

Undoubtedly, data analysis proves that the pandemic which is known as COVID19 has been politicized and used ideologically. In other words, the two selected newspapers namely, The New York Times from the United States of America and 
Global Times from China politicized the pandemic to serve the interests and ideologies of the countries they represent.

Both newspapers invested the three discourse structure namely, macrostructure, superstructure, and microstructure ideologically in their reports. The newspapers gave more emphasis and prominence to the negative stories related to the COVID-19. New York Times put more emphasis on the propaganda of the communist party in China, its inability to control the spread of the outbreak, its weaknesses in controlling the virus, its shortcomings in providing medical supplies, and its totalitarian treatment to the people and medical workers. People are dissatisfied with the government's decisions and shortcomings. Global Times also emphasized the negative stories related to COVID-19 in the US. The US government under Trump's administration is weak and slow in its response to the virus. The US's CDC is described as slow and unprofessional in its response to the outbreak. Negative stories related to the lack of testing kits and medical supplies are repeated and emphasized in the reports. People are angry and anxious due to the government's slow response, American expensive healthcare system and weaknesses are also repeated and given more prominence.

The article recommends that the whole world should work together for peace, safety, and security. Pandemics and epidemics do not know borders or China or United States. Such deadly diseases do not distinguish between a Christian, a Jew, a Muslim or an Atheist. They also do not distinguish between an American, Asian, or European. Therefore, we should work together to save ourselves and the next coming generations.

\section{References}

1. Adida, C.L., K.Y. Dionne, and M.R. Platas. 2017. Ebola, elections, and immigration: how politicizing an epidemic can shape public attitudes. Politics, Groups, and Identities. https://doi. org/10.1080/21565503.2018.1484376.

2. Aini, N., and P. Widodo. 2018. Critical discourse analysis of the bombing attack news: an analysis of Teun A. van Dijk's model. In Advances in social science, education and humanities research, volume 165, 2nd international conference of communication science research (ICCSR 2018).

3. Bukhari, N.H.S., and W. Xiaoyang. 2013. Critical discourse analysis and educational research. IOSR Journal of Research \& Method in Education 3(1): 9-17.

4. Coronavirus Action Plan: A Guide to What You Can Expect Across the UK. 2020. Department of Health and Social Care. https://www.gov.uk/government/publications/coronavirus-action-plan/ coronavirus-action-plan-a-guide-to-what-you-can-expect-across-the-uk. Accessed 24 April 2020.

5. Coronavirus COVID-19 global cases by the Center for Systems Science and Engineering (CSSE) at Johns Hopkins University (JHU). https://coronavirus.jhu.edu/map.html. Accessed 22 May 2020.

6. Cotter, C. 2020. From the 'Spanish Flu' to COVID-19: lessons from the 1918 pandemic and First World War [Blog post]. https://blogs.icrc.org/law-and-policy/2020/04/23/spanish-flu-covid-191918-pandemic-first-world-war/. Accessed 20 May 2020.

7. Drid, T. 2019. The study of news: a discourse analysis perspective. Journal El-Bahith in Human and Social Sciences 10(35): 701-708.

8. European Centre for Disease Prevention and Control. 2020. https://www.ecdc.europa.eu/sites/defau 1t/files/documents/RRA-outbreak-novel-coronavirus-disease-2019-increase-transmission-globallyCOVID-19.pdf. Accessed 24 April 2020. 
9. Hofstetter, C.R., and T.F. Buss. 1978. Bias in television news coverage of political events: a methodological analysis. Journal of Broadcasting 22(4): 517-530. https://doi.org/10.1080/0883815780 9363907.

10. Huang, J. 2020. Chinese diplomat accuses US of spreading coronavirus [blog post]. https://www. voanews.com/science-health/coronavirus-outbreak/chinese-diplomat-accuses-us-spreading-coron avirus. Accessed 20 May 2020.

11. Illustration of the ultrastructure of the Covid-19 virus-CDC/SCIENCE PHOTO LIBRARY. https:// www.newscientist.com/term/covid-19/.

12. Kolsto, P. 2009. Media discourse and the Yugoslav conflicts: representations of self and other. Farnham: Ashgate.

13. Little, B. 2020. Trump's 'Chinese' virus is part of a long history of blaming other countries for disease [blog post]. https://time.com/5807376/virus-name-foreign-history/. Accessed 20 May 2020.

14. Marcus, J. 2020. Coronavirus: US-China battle behind the scenes [blog post]. https://www.bbc. com/news/world-52008453. Accessed 20 May 2020.

15. Mullainathan, S., and A. Shleifer. 2002. Media Bias. Harvard Institute Research Working Paper No. 1981; MIT Department of Economics Working Paper No. 02-33. Available at SSRN: https://ssrn. com/abstract=335800. http://dx.doi.org/10.2139/ssrn.335800.

16. Myers, S. L. 2020. China spins tale that the U.S. army started the coronavirus epidemic [blog post]. https://www.nytimes.com/2020/03/13/world/asia/coronavirus-china-conspiracy-theory.html. Accessed 20 May 2020.

17. Nelson, R.A. 2003. Tracking propaganda to the source: tools for analyzing media bias. Global Media Journal 2(3): 1-7.

18. Page, C. 2020. Page: politicizing coronavirus hazardous to our national health [blog post]. https ://www.telegraphherald.com/ap/commentary/article_58ffbb41-0b5d-5ac2-bfc1-bc590ad5a699.html. Accessed 20 May 2020.

19. Pratiwi, A., and R. Refnaldi. 2018. Macrostructure and superstructure patterns of Jokowi's speeches. E-Journal of English Language \& Literature 7(4): 547-556.

20. Qiu, L. 2017. Fingerprints of Russian disinformation: from AIDS to fake news [blog post]. https:// www.nytimes.com/2017/12/12/us/politics/russian-disinformation-aids-fake-news.html. Accessed 20 May.

21. Scott, C. 2014. The Ebola outbreak was political-just like every disease outbreak [blog post]. https ://www.theverge.com/2014/12/30/7466989/the-ebola-outbreak-was-political-just-like-every-disea se-outbreak. Accessed 20 May 2020.

22. Thomas, L., W. Shan, S. Ishtla, S.P. Jean, T. Joanna, and J. Jason. 2004. Language, society, and power: an introduction. London: Routledge.

23. Van Dijk, T.A. 1985. Structures of news in the press. In Discourse and communication, ed. T.A. Van Dijk. Berlin: De Gruyter.

24. Van Dijk, T.A. 1988. News as discourse. Hillsdale, NJ, US: Lawrence Erlbaum.

25. Van Dijk, T.A. 1988. News analysis: case studies of international and national news in the press. Hillsdale, NJ: Erlbaum.

26. Van Dijk, T.A. 1991. Racism and the press. London: Routledge.

27. WHO. 2020. Coronavirus disease 2019 (COVID-19) situation report-41. https://www.who.int/ docs/default-source/coronaviruse/situation-reports/20200301-sitrep-41-covid-19.pdf?sfvrsn=67683 06d_2.

28. Yarlott, W. V. H., C. Cornelio, T. Gao, and M. A. Finlayson. 2018. Identifying the discourse function of news article paragraphs. In: Proceedings of the workshop on events and stories in the news, 25-33 Santa Fe, New Mexico, USA.

29. Zhang, X., Y. Pan, and M. Zhang. 2014. Superstructure analysis in news stories: a contrastive study of superstructure in VOA, BBC, and NPR news. Asian Social Science 10(22): 199-209.

\section{The New York Times Reports}

30. China Clamps Down on Coronavirus Coverage as Cases Surge. https://www.nytim es.com/2020/02/05/world/asia/china-coronavirus-censorship.html action=click \&module=Relat edLinks\&pgtype $=$ Article. 
31. Coronavirus Weakens China's Powerful Propaganda Machine. https://www.nytim es.com/2020/02/26/business/china-coronavirus-propaganda.html.

\section{Global Times Reports}

32. US COVID-19 numbers 'tip of iceberg'. http://www.globaltimes.cn/content/1181754.shtml.

33. US scrambles to tackle virus. http://www.globaltimes.cn/content/1181262.shtml.

Publisher's Note Springer Nature remains neutral with regard to jurisdictional claims in published maps and institutional affiliations. 